\title{
Profil Cabang Olahraga Unggulan Papua (Studi Deskriptif Berdasarkan Perolehan Medali)
}

\author{
Saharuddin Ita \\ ${ }^{a}$ Fakultas Ilmu Keolahragaan, Universitas Cenderawasih,Papua, Indonesia
}

*Corresponding author: saharuddinita@yahoo.com

\section{A R T I C LE INFO}

\section{Article history:}

Received 14 April 2017

Received in revised form 20 April 2017

Accepted 29 April 2017

\section{Keywords:}

Profile, Sport, Papua

\begin{abstract}
A B S T R A C T
The purpose of this study was to know the profile of the sport featured on the side of the Papua medals on fifth consecutive National Sports Competion of Indonesia (PON). The method used was descriptive method to verify the data sport that gained the gold medal in the last 5 times participating on PON. Popolation in this study were all built by KONI Papua province include of 42 sports. The samples on this research was the sport that gained medals in the last 5 PON. Sports result that consistently win gold medals in 5 Last PON respectively were athletics, PODSI (Canoes, kayaks, dragon boats) and PABBSI (weightlifting, weight lifting and body building) as the flagship sport of Papua.
\end{abstract}

\section{Pendahuluan}

Keberhasilan suatu daerah dalam bidang pembangunan terutama dalam pembangunan Sumber Daya Manusia salah satunya dapat dilihat dari maju tidaknya pembinaan olahraga didaerah tersebut yang didasarkan pada prestasi olahraga yang diraih oleh para atletnya baik secara nasional maupun internasional. Pembinaan olahraga pada suatu daerah banyak terbantu dari bahan baku atlet yang ada secara alami didaerah tersebut.

Provinsi Papua adalah salah satu daerah di Indonesia yang banyak menyimpan bibit unggul olahraga potensial yang apabila dikelolah secara professional dengan manajemen yang baik akan dapat memunculkan prestasi tinggi olahraga Indonesia. Apabila dilihat dari latar belakang kebudayaan, suku bangsa Papua sangat beraneka ragam yang tersebar dari ujung timur kota Jayapura dipesisir utara dan kota Merauke dipesisir bagian selatan sampai ujung barat kota sorong. Secara etnografi Provinsi Papua yang terdiri dari beratus-ratus etnis yang dalam penyebarannya secara ekologis-geografis berbeda antara pesisir pantai dan lembah, danau, perbukitan dan kepulauan. Keadaan ekologis-geografis ini menyebabkan tiap kelompok etnis ini mempunyai batas-batas wilayah, bahasa dan budaya. Dari keberaneka ragaman inilah muncul berbagai corak, bentuk dan karakteristik manusia dengan ciri khas masing-masing.

Pada beberapa event olahraga baik pada skala Nasional, Regional maupun Internasional atlet-atlet dari Papua dibeberapa cabang olahraga dapat mencapai prestasi yang cukup baik. Salah satu atlet Papua yaitu Lisa Rumbewas dari cabang olahraga angkat besi putri sudah menyumbangkan 2 medali perak pada 2 Olympiade yang berbeda yaitu pada olympiade Sydney tahun 2000 di Australia dan Olympiade Athena tahun 2004 di Yunani. Di beberapa cabang olahraga lainnya seperti dayung, atlet putri Papua yaitu Perlina Karoba sudah berlaga di Olympiade walaupun belum memperoleh medali, kemudian dari cabang olahraga atletik putra, atlet dari Papua yaitu Yanes Raubaba dan Jhon Murray juga telah sampai pada olympiade yaitu Olympiade Sydney tahun 2000 di Australia namun belum memperoleh medali dan hanya sampai pada babak penyisihan. Dari cabang olahraga beladiri seperti Pencak Silat atlet dari Papua yaitu Imanuel Daundi di bagian putra dan Waode Hanifa dibagian putri pernah menjadi juara dunia, kemudian di cabang olahraga beladiri lainya yaitu tinju, atlet Papua yaitu Benny Maniani menjadi juara Asian Games serta dari cabang Karate atlet Papua yaitu Novilus Yoku sudah berprestasi di tingkat SEA Games serta cabang Yudo yang telah melahirkan nama-nama seperti Hanna Yawan dan Mahuse juga sudah beberapa kali memperkuat kontingen Indonesia di SEA Games dan masih banyak lagi nama-nama atlet Papua lainnya dari nomor perseorangan. Dicabang olahraga beregu seperti sepakbola, banyak atlet Papua yang sudah memperkuat kesebelasan Indonesia ditingkat Regional maupun Internasional. Prestasi sepak bola Papua di tingkat Nasional, yaitu beberapa kali menjadi juara Pekan Olahraga Nasional, juara perserikatan dan di Liga sepak bola Indonesia yaitu Liga jarum Indonesia, Persipura Jayapura menjadi juara pada musim kompetisi 2005 serta menjadi ranner up pada Copa Indonesia di tahun 2006, dan di Liga Indonesia Persipura menjadi juara sebanyak 4 kali. Cabang olahraga bola Voli pasir putri tercatat nama seperti Engel Berta Kaise dan Depota Rahawarin Yokbet Kapasiang sudah pernah memperkuat Indonesia di arena Regional maupun Internasional. Kemudian cabang olahraga beregu lainnya seperti Hockey atlet putra maupun putri Papua sudah beberapa kali menjadi juara pada Pekan Olahraga Nasional PON. Dari beberapa fakta tersebut di atas inilah menjadi dasar yang kuat bagi dunia olahraga Indonesia bahwa Provinsi Papua merupakan salah satu daerah potensial olahraga prestasi Indonesia.

Hal tersebut sesuai dan sejalan dengan sistim pembinaan yang dilakukan oleh Koni Daerah (Konida) Papua yang membagi cabang olahraga prestasi kedalam beberapa skala prioritas yaitu prioritas utama, prioritas satu, dua, tiga dan empat. Hal tersebut juga sejalan dengan anamat UU RI No. 3 tahun 25 pasal 21 ayat 1 yang mengatakan bahwa Pemerintah dan Pemerintah Daerah wajib melakukan pembinaan dan pengembangan olahraga sesuai dengan kewenangan dan tanggung jawabnya (UU RI NO. 3 , 2005 : 21). Selanjutnya Pada Pasal 34 ayat 2 dikatakan bahwa pemerintah kabupaten/kota wajib mengelola sekurang- 
kurangnya satu cabang olahraga unggulan yang bertaraf nasional dan atau internasional.

Prioritas utama yaitu cabang olahraga yang selama ini telah menyumbang medali emas pada Pekan Olahraga Nasional PON, kemudian prioritas satu yaitu cabang olahraga yang telah menyumbangkan medali perak pada Pekan Olahraga Nasional dan prioritas dua yaitu cabang olahraga yang telah menyumbangkan medali perunggu pada Pekan Olahraga Nasional serta prioritas tiga adalah cabang olahraga yang belum mendapatkan medali apapun pada Pekan Olahraga Nasional dan prioritas empat yaitu cabang olahraga yang diperkirakan akan mendapatkan hasil medali emas apabila ditangani dengan tepat. Oleh sebab itulah dari 42 cabang olahraga yang dibina Koni Papua cabang olahraga mana yang secara konsisten menyumbangkan medali emas dalam 5 PON terakhir secara berturut-turut?

Menurut Mutohir (2002: 28) pembinaan olahraga prestasi yang dilakukan, baik KONI Pusat, KONI Daerah dan Pengprov-Pengprov belum dilakukan secara berjenjang dan berkesinambungan disamping itu para pengurus yang ada di induk-induk organisasi cabang olahraga dan pengprov harus lebih professional dibidangnya. Dari perjalanan dan kiprah KONI sebagai lembaga pembinaan olahraga prestasi dan jalur non pemerintah tersebut belum sinergis dengan program-program yang dilaksanakan oleh pemerintah khususnya Depdiknas dalam menangani pembinaan olahraga.

Jika kita cermati proses pembinaan olahraga Nasional, sebenarnya berawal dari munculnya olahragawan dari daerah, kemudian dibawah ketingkat nasional, dan berahir pada tingkat Internasional. Dari daerah terbagi menjadi kota/kabupaten dan kecamatan. Oleh karna itu pembinaan olahraga unggulan daerah sudah seharusnya mendapat perhatian. Dan jika hal ini dapat dilakukan dengan baik secara berjenjang dan berkelanjutan dengan keterlibatan semua stake holder, bukan tidak mungkin suatu saat Indonesia dengan penduduk yang begitu besar akan dapat berbicara dan bersaing didunia Internasional dan dapat sejajar dengan Negara lain didunia yang sudah lebih duluan maju dibidang prestasi olahraga.

Namun demikian kita dapat melihat bahwa prestasi olahraga secara Nasional belum merata disemua provinsi. Hal ini dapat dilihat dari penyelenggaraan Pekan Olahraga Nasional (PON) yang sudah ke 19 kalinya setelah diselengarakan untuk pertama kalinya pada tahun 1948 di kota Surakarta Solo Jawa Tengah. Hingga PON XIX/2016 di Jawa Barat terlihat bahwa perolehan medali terbanyak masih didominasi oleh provinsi di pulau jawa dan belum sekalipun dalam PON tersebut rangking 4 besar bergeser dari pulau jawa. Hal ini berarti bahwa pembangunan peningkatan SDM melalui olahraga dibeberapa daerah ditanah air belum mendapat perhatian yang serius dari pemerintah daerahnya. Untuk bisa mengimbangi kemajuan dibidang olahraga ada beberapa faktor yang harus menjadi perhatian.

a. Faktor Sumber Daya Manusia (SDM).

Upaya pengembangan dan peningkatan sumber daya manusia dibidang olahraga dimaksudkan untuk meningkatkan kemampuan dalam berbagai kegiatan olahraga dan kinerja berupa prestasi yang diinginkan. Sumber daya manusia tersebut dapat dipengaruhi oleh banyak faktor baik internal maupun eksternal berupa wawasan terhadap kemajuan suatu cabang olahraga khusunya cabang olahraga yang menjadi unggulan di daerah tersebut.

Kehadiran sarana prasarana sebagai faktor pendukung pembinaan yang setiap saat perkembangannya sangat pesat tidak mungkin terpisah dengan hadirnya SDM dibidang infrastruktur. Sudah menjadi tradisi umum bahwa faktor ini sering menjadi benturan di daerah-daerah ketika tuntutan cabor yang harus menggunakan sarana yang standar sesuai ketentuan induk organisasi. Namun demikian, hal tersebut dapat diminimalisir dengan adanya perhatian berupa komitmen dan kebijakan oleh pemerintah daerah maupun swasta untuk memperhatikan dengan sunguh-sungguh secara professional mengenai faktor sarana tersebut. Pemerintah pusat maupun daerah sudah saatnya untuk membangun sarana dan prasarana olahraga yang sesuai dengan kebutuhan olahraga unggulan daerahnya masing-masing sehingga prestasi yang dicapai di daerah ikut memberi andil dalam akselerasi prestasi olahraga secara Nasional. Keberadaan sarana prasarana olahraga didaerah harus di imbangi dengan keberadaan sumber daya manusia yang paham dan mengerti secara teknis akan sarana pendukung setiap cabang olahraga di daerah apalagi yang termasuk dalam cabang olahraga unggulan yang diharapkan sebagai icon olahraga dari daerah tersebut, sudah tidak mungkin terlepas dari kehadiran SDM yang berkompeten.

Koni pusat dalam dalam menjalankan salah satu program pemerintah dibidang olahraga yaitu Indonesia Bangkit mengatakan bahwa Perlu adanya pemberdayaan pelatih potensial daerah, yaitu memberikan kesempatan kepada pelatih cabang olahraga potensial didaerah sebanyak 5 orang untuk mendapatkan insentif setiap bulan dari KONI pusat dengan maksud untuk meningkatkan kinerjanya. Makna dari hal tersebut diatas ini tidak lain adalah merupakan rentetan dari percepatan atau akselerasi prestasi olahraga Nasional melalui peningkatan dukungan dari prestasi atlet-atlet potensial yang ada di daerah untuk menunjang prestasi olahraga Nasional.

\section{b. Faktor Lingkungan.}

Sebagai olahraga unggulan daerah tidak bisa dipisahkan dengan lingkungan, baik lingkungan geografis, maupun lingkungan industri olahraga. Lingkungan geografis merupakan alam sekitarnya dimana para olahragawan hidup dan melakukan aktivitas sehari-hari, sehingga corak dan karasteristik olahragawannya ikut dipengaruhi oleh letak geografis secara keseluruhan. Bahkan dengan lingkungan itu sendiri dimana para atlet dilatih dan ditempah menjadi seorang yang mempunyai karakter, akan berpolah dan berkarakter sesuai dengan daerah dimana ia berlatih. Kalau didaerah yang kehidupannya keras seperti Papua, sudah barang tentu akan melahirkan karakter yang berbeda dengan para atlet yang dilahirkan dan berlatih di daerah jawa yang sudah lebih maju dan lebih baik dalam taraf kehidupannya. Bahkan letak geografis dan budaya daerah tersebut akan melahirkan ciri khas daerhnya yang secara otomatis akan ikut mewarnai karakter yang diperlihatkan oleh atlet daerah tersebut.

Daerah Papua seperti yang telah disebutkan di atas dimana terbagi atas daerah lembah, pesisir dan daerah pengunungan serta dihuni berbagai macam suku yang mendiami pulau Papua yang begitu luas, akan memunculkan berbagai karakter dan budaya serta bentuk antropometri tubuh dengan ciri khas dari suku dari masing-masing daerah. Masyarakat yang mendiami daerah pesisir selatan seperti suku Marind-Anim di Merauke, Teluk Arguni di manokwari, Mimika di Timika, Mamberamo, Sentani dan teluk Yos Sudarso di Jayapura mempunyai tinggi badan ratarata ditas $167 \mathrm{~cm}$ sedangkan masyarakat atau suku yang mendiami lembah dan pegunugan seperti suku Muyu di pegunungan Merauke dan suku dani di lembah Baliem Jayawijaya mempunyai tinggi badan yang lebih pendek daripada suku-suku yang mendiami pesisir pantai yaitu rata-rata $149 \mathrm{~cm}$ ( Muller 2011: 20). 
Dari keberaneka ragaman bentuk tubuh dan ciri khas yang mewakili kelompok dan etnis masing-masing inilah kemudian dapat dipilah dan dipilih untuk dilatih dalam berbagai cabang olahraga yang sesuai dengan kebutuhan cabang olahraga tersebut, yang nantinya akan menjadi olahraga unggulan daerah masing-masing. Selama ini sudah ada beberapa atlet Papua yang telah mewarnai setiap pemusatan latihan nasional (pelatnas) yang dipusatkan di Jakarta, namun jumlahnya masih sangat kecil baik dalam jumlah cabang maupun olahragawannya atau atletnya seperi atletik nomor lari dan lempar, angkat besi, angkat berat, Bina raga, karate, Voli, yudo, hoki dan dayung.

Dari sekian banyak etnis orang Papua baik yang bermukim dipesisir pantai maupun yang bermukim di lembah dan pengunungan, masingmasing mempunyai kelebihan dan kekurangan. Begitu juga dengan sukusuku Papua yang tersebar dibeberapa kabupaten dan Kota akan membawah dan mempunyai ciri khas tersendiri yang juga berimbas kepada cabang olahraga yang ditekuni mereka hingga sekarang. Dalam pengelompokan daerah sebagai peta kekuatan cabang olahraga tertentu masing-masing daerah atau kabupaten mempunyai cabang olahraga unggulan. Sebagai gambaran peta olahraga unggulan Papua dapat dilihat di beberapa daerah berikut ini.

1. Kabupaten Merauke dan sekitarnya: Atletik nomor lempar, voli, sepakbola.

2. Kabupaten Boven Digul: Yudo, bina raga, angkat besi dan angkat berat.

3. Kabupaten Asmat: Atletik nomor lempar, Sepakbola, Judo.

4. Kabuapten Mappi: Atletik nomor lempar

5. Kota Jayapura dan sekitarnya: Dayung, Silat, Karate, Sepakbola, Judo, Voli, Angkat Besi

6. Kabupaten Jayapura: Dayung, Silat, Karate, Sepakbola, Judo,

7. Kabupaten Yapen: Atletik nomor jarak pendek, nomor lompat, dayung, Pencak Silat

8. Kabupaten Biak Numfor: Atletik lari jarak pendek dan menengah, lempar, tinju, gulat, silat dan sepak bola serta judo

9. Kabupaten Puncak Jaya: sepak bola, angkat besi, marathon dan gulat

10. Kabupaten Jayawijaya: sepak bola, angkat berat, angkat besi, tinju dan maraton.

11. Kabupaten Waropen: Silat, karate, dayung, tinju dan judo

12. Kabupaten Yapen : Atletik, karate, dayung, tinju ,Pencak Silat.

13. Kabupaten Sarmi: Nomor lempar, silat, angkat besi, gulat dan tinju

14. Kabupaten Mimika: Nomor lempar, karate, angkat berat dan besi, dayung.

15. Kabupaten Pegunungan Bintang:Angkat Besi, Maraton, Tinju

16. Kabupaten Yahukimo: Tinju, marathon, gulat

17. Kabupaten Supiori: Tinju, karate, gulat, tinju sepak bola

18. Kabupaten Tolikara: Maraton, gulat, tinju sepak bola (Koni Papua 2010).

19. Kabupaten Nabire, Dogiay, Deiyai dan paniai : Atletik, Voli, angkat berat, Tinju, taekwondo, muaythai, sepakbola,

20. Kabupaten Maberamo dan sekitarnya: Lari jarak jauh, Dayung, tinju, angkat berat, besi dan bina raga

\section{c. Letak Geografis dan Budaya}

Wilayah Provinsi Papua terdiri dari 29 kabupaten dan Kota. Daerah Provinsi Papua terletak pada posisi 010 00' - 060 30' lintang selatan dan $133030^{\prime}-136015^{\prime}$ Bujur timur dan menempati wilayah paling timur dari negara Republik Indonesia serta berbatasan langsung dengan Negara tetangga Papua New Guinea. Luas daerah Papua adalah 31.612.208,00 Ha dengan wilayah terluas adalah Kabupaten Merauke yaitu 4.397.931,00 Ha (13.91\%) dan terkecil adalah Kabupaten Supiori yaitu 77.456,00 Ha $(0.25 \%)$. Batas administrasi Provinsi Papua adalah sebagai berikut:

- Sebelah Utara berbatasan dengan samudra Fasifik

- Sebelah Selatan berbatasan dengan laut Arafura

- Sebelah Timur berbatasan dengan Negara Papua New Guinea

- Sebelah Barat berbatasan dengan laut Seram, Provinsi Papua Barat (Kab. Kaimana, Teluk Wondama dan Manokwari).

Provinsi Papua terletak tepat disebelah selatan garis katulistiwa sehingga secara umum Provinsi Papua beriklim tropis, namun karena daerahnya bergunung-gunung sehingga iklimnya sangat bervariasi melebihi daerah Indonesia lainnya. Berdasarkan hasil catatan dari Badan Metrologi dan Geofisika Papua, Suhu rata-rata adalah 270-310C. Suhu terendah terjadi di Wamena dan tertinggi di Sentani (Jayapura). Sedangkan kelembaban udara rata-rata tertinggi terjadi di Biak $85 \%$ dan terendah di Merauke yaitu 78\%.

Dengan jumlah penduduk yang relatif masih kecil ini memungkinkan masyarakat untuk bergerak bebas dengan ruang terbuka hijau yang begitu luas jika dibandingkan dengan daerah lain di perkotaan dengan luas ruang terbuka yang sudah semakin sempit. Dengan penyebaran penduduk yang tidak merata ini memungkinkan mereka dalam berhubungan satu sama lain harus menempuh perjalanan yang begitu jauh dan melelahkan karena dukungan sarana transportasi yang masih kurang, bahkan sampai dengan tahun 2016 ini sektor perhubungan (transportasi) masih menempati urutan pertama dalam skala prioritas pembangunan di Provinsi Papua.

Dengan berjalan kaki untuk kunjungan diantara sesama keluarga pada dasarnya mereka telah melakukan latihan fisik secara langsung yang pada akhirnya secara otomatis telah membentuk tubuh orang Papua menjadi kuat secara alami. Oleh karena itu orang Papua secara fisik sebetulnya sudah terbentuk secara alami akibat letak geografis yang bergununggunung dan penduduknya yang masih jarang, sehingga dalam memantau bibit unggul untuk olahraga prestasi tidak terlalu sulit sebenarnya karena sudah tersedia secara merata dialam Papua yang begitu luas. Dengan demikian, dalam memantau atlet potensial tinggal manambah sentuhan IPTEK olahraga dalam memilih atlet (talent scouting) untuk selanjutnya dibina dalam suatu program pelatihan yang terarah, berjenjang dan berkelanjutan untuk dapat membentuk atlet yang potensial bagi daerah Papua Khususnya dan prestasi olahraga Nasional pada umumnya.

Dengan banyaknya suku dan etnis yang ada dan mendiami pulau Papua dengan budaya dan cara hidup yang sangat beraneka ragam dengan ciri khas sendiri-sendiri, maka terdapatlah perbedaan antara suku yang satu dengan suku yang lainnya. Jika dilihat dari latar belakang budaya secara umum, suku bangsa di Irian (sekarang Papua) yang beraneka ragam tersebut menurut para ahli Ekologi antara lain Tucker dan Petocz sebagaimana yang ditulis kembali oleh Mientje De Roembiak (1993) bahwa di Papua terdapat 11 daerah kebudayaan yaitu:

1. Kebudayaan penduduk di daerah kepulauan pesisir teluk Cenderawasih

2. Kebudayaan penduduk pesisir pantai utara.

3. Kebudayaan penduduk Pulau-pulau Raja Ampat.

4. Kebudayaan penduduk kawasan teluk Bintuni, Fak-fak dan kaimana.

5. Kebudayaan penduduk di daerah hutan dataran rendah (disekitar Danau Sentani sampai wilayah pesisir pantai menuju ke perbatasan dengan Negara Papua New Guinea dan Indonesia. 
6. Kebudayaan penduduk di daerah sungai-sungai dan rawa di bagian selatan Papua yaitu Merauke, Asmat dan sekitarnya.

7. Kebudayaan penduduk di daerah sabana disekitar Merauke utara dan Nimboran.

8. Kebudayaan penduduk di daerah kaki selatan pegunungan Jayawijaya.

9. Kebudayaan penduduk di daerah punggung pegunungan Jayawijaya, yaitu daerah arfak dan kawasan danau ayamaru (kepala burung).

10. Kebudayaan penduduk di daerah kawasan pedalaman sungai-sungai di daerah mamberamo-Rouffaer - Idenburg.

11. Kebudayaan penduduk Papua yang telah berimigrasi ke kota dan pesisir pantai.

Melihat keaneka ragaman budaya yang terdapat di Provinsi Papua tersebut, sudah barang tentu masing-masing koloni atau kelompok etnis tersebut akan membawah ciri khas masing-masing sesuai dengan keadaan alam dimana mereka tinggal dan melanjutkan keturunan.

\section{d. Ciri-Ciri Antropologi Fisik}

Secara khusus kelompok-kelompok etnik di Papua banyak diditeliti dan ditulis oleh para ahli Antropologi di antaranya adalah Kleiweg de Zwaan dan peneliti T.H.J. Bijlmer. Dalam penemuan mereka dikatakan bahwa terdapat perbedaan secara antropometri fisik antara penduduk yang tinggal atau mendiami kawasan pesisir dengan penduduk yang mendiami kawasan lembah dan pegunungan. Tinggi badan bagi mereka yang mendiami pesisir dan pantai seperti di Merauke rata-rata lebih tinggi dibandingkan dengan mereka yang mendiami lembah dan pegunungan. Tinggi badan rata-rata pendduk suku Marind-Anim di Mearuke adalah $167,2 \mathrm{~cm}$, Mimika 165,3 cm, Teluk Arguni 164,4 cm, Mamberamo 162,5 $\mathrm{cm}$, Teluk Yos Sudarso 163,4 cm dan Sentani 159,5 cm. Sedangkan yang ada di pegunungan rata-rata 144,9-155 cm (Pattipi, 1993).

\section{e. Karakteristik Penduduk}

Provinsi Papua sebagaimana yang telah disebutkan diatas yang terdiri dari banyak suku dan budaya akan turut mempengaruhi karakteristik orang Papua pada umumnya. Walaupun tidak dapat diuraikan satu persatu mengenai karakteristik masing-masing suku dengan adat istiadatnya secara rinci, akan tetapi kita dapat mengatakan bahwa pada umumnya karakter orang papua adalah keras. Ini dapat dilihat dengan banyaknya perang suku diantara sesama mereka yang sudah banyak memakan korban jiwa. Mengenai perang suku tersebut sampai sekarang masih sering terjadi, bahkan ditahun 2016 sekarang ini masih terdapat perang antar suku yaitu di Kwamki lama Timika yang juga menimbulkan korban pada kedua belah pihak atau suku yang berperang. Hal ini menunjukkan bahwa suku-suku yang ada di Papua masih saling bermusuhan satu dengan lainnya dan masih mempertahankan adat dan budaya yang ada pada kelompoknya masing-masing, sehingga turut mempengaruhi jiwa dan karakter orang papua dengan egoisme yang besar dalam mempertahankan kelompoknya.

\section{f. Cabang Olahraga Unggulan}

Seperti yang kita ketahui bahwa tipe tubuh orang papua termasuk dalam tipe tengah atau meshomorph yang berarti bahwa dapat dibina pada berbagai cabang olahraga prestasi. Dalam aspek olahraga yang diunggulkan tersebut kita dapat melihatnya dari 3 indikator yaitu; 1. Jenis Olahraganya apakah perorangan atau beregu. Jenis olahraga yang cocok untuk orang papua adalah olahraga yang menantang karena itu sesuai dengan karakteristik orang papua yang senang berpindah tempat dan berpetualang dari satu tempat ketempat yang lain untuk menyambung kehidupan. Masyarakat yang suka berpindah tempat akan mengalami suatu aklimatisasi dengan alam setiap saat. Mereka harus menaklukkan alam sekitarnya untuk bisa menguasai tempat barunya termasuk sesama penghuni alam setempat. Dalam keadaan seperti ini pertikaian atau bahkan sampai peperangan harus terjadi karena perebutan kekuasaan lahan. Secara tidak langsung aktifitas di alam inilah menjadi awal dari terbentuknya fisik orang irian secara alamiah dan apabila dilanjutkan dalam bentuk olahraga prestasi maka satu program sudah bisa terlewati yaitu latihan fisik. 2) Perolehan medali emas. Kalau ingin mengejar perbaikan rangking atau berdasarkan perolehan medali emas maka olahraga perorang dapat menjadi pilihan karena 1 orang dapat merebut lebih dari satu medali seperti atletik, renang, senam dan menembak. Secara pembinaan cabor perorangan dapat menekan biaya secara efisien dan efektif jika dibanding dengan cabor beregu. dan, 3) Potensi perolehan medali pada PON XX tahun 2020 di Papua. Seperti yang telah diuraikan diatas bahwa jenis cabang olahraga unggulan untuk Provinsi Papua adalah dominan olahraga perorangan seperti; Atletik, dayung, angkat berat, angkat besi dan bina raga. Cabang olahraga inilah yang selama 5 PON terakhir masih menyumbangkan medali emas secara konsisten. Kemudian cabang olahraga lainnya seperti Tinju, karate, Pencak Silat dan Yudo dan gulat serta cabang olahraga rakyat yang beregu yaitu sepakbola, voli, basket dan hockey. Juga merupakan Cabang olahraga yang selama 5 PON terakhir masih menyumbangkan medali pada kontingen Papua namun tidak konsisten. Dengan terverifikasinya beberapa cabang beberapa cabang olahraga unggulan papua tersebut di atas maka potensi penambahan perolehan medali bagi Provinsi Papua pada PON XX tahun 2020 di Papua sangat terbuka dan mentargetkan berada pada rangking V dengan perkiraan perolehan medali emas antara 25-35 buah

\section{Metode}

Metode yang digunakan dalam penelitian ini adalah metode survei dengan analisis deskriptif kualitatif. Penelitian ini dilaksanakan dari bulan oktober sampai dengan bulan Desember 2016 di KONI Provinsi Papua. Populasi dari penelitian ini adalah seluruh cabang olahraga prestasi binaan KONI Provinsi Papua yaitu 42 cabang olahrga. Sedangkan sample adalah cabor yang meraih medali (emas, perak, perunggu) pada 5 PON terakhir yaitu dari PON XV tahun 2000 sampai dengan PON XIX tahun 2016. Teknik Pengumpulan data adalah dengan teknik Observasi, verifikasi dan dokumentasi yaitu mendata perolehan medali baik emas, perak maupun perunggu dari setiap cabang olahraga yang dibina Koni Papua pada 5 PON terakhir yaitu mulai dari PON XV/2000 - XIX/2016. Selanjutnya dari verikasi data tersebut maka secara jelas dapat dilihat dan ditetapkan cabang olahraga mana yang secara konsisten memberikan kontribusi medali emas dalam 5 PON terakhir secara berturut-turut.

\section{Hasil dan diskusi}

\section{Hasil}

Dari hasil verifikasi data tentang cabang olahraga yang dapat meraih medali pada 5 PON terakhir dari 42 cabang olahraga binaan KONI Papua terlihat bahwa sampai dengan PON XIX/2016 terdapat 30 cabang orahraga yang bisa meraih medali baik emas, perak maupun perunggu. Dari 5 pelaksanaan PON terakhir tesrsebut dapat dilihat bahwa tidak semua cabang olahraga bisa meraih medali emas secara konsisten pada setiap penyelenggaraan PON selama $5 \mathrm{kali}$, artinya selalu berubah-ubah dari PON ke PON dan hanya beberapa cabang olahraga saja yang konsisten memberikan kontribusi medali baik emas perak maupun 
perunggu. Khusus untuk cabang olahraga yang meraih medali emas secara berturut-turut dalam 5 PON terakhir hanya ada 3 cabang olahraga yaitu Atletik, Dayung dan Pabsi (angkat berat, angkat besi dan binaraga) selebihnya adalah medali perak dan perunggu secara bervariasi.

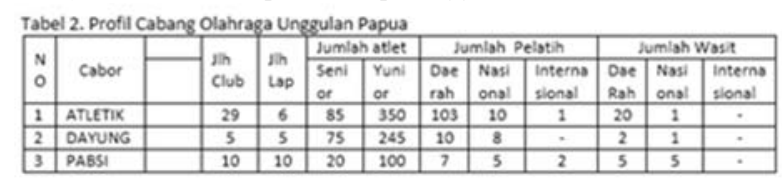

47 Tabel 3. Keberadaan Olahraga Unggulan Provinsi Papua
\begin{tabular}{|c|c|c|c|c|c|}
\hline Urutan Cabang Olahraga Unggulan Berdasarkan Perolehan Medali Emas \\
\hline N & Cabang & Jumlah Klub & Perolehan Medali Pada 5 PON Terakhir \\
\cline { 4 - 6 } 0 & Olahraga & & Emas & Perak & Perunggu \\
\hline 1 & ATLETK & 29 & 19 & 21 & 23 \\
\hline 2 & DAYUNG & 5 & 27 & 20 & 21 \\
\hline 3 & PABSI & 10 & 9 & 3 & 7 \\
\hline
\end{tabular}

\section{a. Peran Pemerintah dalam Pengembangan Olahraga}

Maju mundurnya olahraga di tanah air mulai dari daerah sampai ke pusat tidak terlepas dari peran pemerintah, terutama olahraga prestasi Keseriusan pemerintah secara inplisit tertuang dalam undang-undang Nomor 3 tahun 2005 tentang Sistim Keolahragaan Nasional Bab I pasal 1 ayat 13: Bahwa Olahraga prestasi adalah olahraga yang membina dan mengembangkan olahragawan secara terencana, berjenjang dan berkelanjutan melalui kompetisi untuk mencapai prestasi dengan dukungan ilmu pengetahuan dan teknologi keolahragaan. Upaya tersebut juga tertuang dalam pasal 27 ayat 3 yang mengatakan bahwa pembinaan dan pengembangan olahraga yang dimaksud pada ayat (1) dan (2) dilakukan oleh pelatih yang memiliki kualifikasi dan sertifikat kompentensi yang dapat dibantu oleh tenaga keolahragaan dengan pendekatan ilmu pengetahuan.

Prestasi Papua pada pesta olahraga multi event Nasional PON pada 5 PON terahir yaitu dari PON XV tahun 2000 di Surabaya dan PON XVI tahun 2004 di Palembang masih berada di urutan 7 namun PON XVII tahun 2008 di kalimantan Timur menjadi titik rawan prestasi bagi Papua karena dari urutan 7 menjadi urutan 11 dalam perolehan medali. Kemudian pada PON XVIII tahun 2012 menjadi titik terendah bagi prestasi Papua yaitu berada pada rangking 15 dengan perolehan medali (912-13). Setelah itu pada PON XIX tahun 2016 di jawa barat Papua mulai bangkit lagi baik dari segi perolehan medali emas maupun secara rangking yaitu rangking 7 dengan perolehan medali (19-18-32). Dan bukan tidak mungkin rangking papua akan terus membaik lagi pada PON XX tahun 2020 ketika PON dilaksanakan di tanah Papua sendiri.

Dengan mengetahui bahwa cabor yang konsisten menyumbangkan medali emas untuk Papua dalam 5 PON berturut-turut baru ada 3, maka pemerintah harus menjamin keberlangsungan 3 cabor ini agar tetap berlatih dan tetap mengikuti kompetisi agar aroma kompetisinya tidak hilang dan tetap dalam keadaan siap berkompetisi dalam setiap kejuaraan. Selain 3 cabor tersebut masih ada beberapa cabor lagi yang apabila di perhatikan dengan serius oleh pemerintah bersama induk cabornya bukan tidak mungkin PON yang akan datang semakin banyak cabor yang bisa menyumngkan medali emas dan pada akhirnya bisa mengangkat dan merubah rangking Papua yang lebih baik.

Untuk mewujudkan cita-cita Provinsi Papua tersebut, maka faktorfaktor penentu yang perlu mendapat perhatian adalah: (1) Adanya komitmen dan kebijakan Pemerintah daerah dalam pembinaan olahraga di Provinsi papua, (2) Kinerja optimal dari organisasi keolahragaan, (3) Prioritas cabang olahraga unggulan, (4) sistim rekruitmen atlet yang tepat, (5) Ketersediaan dan penyebaran sarana dan prasarana olahraga unggulan di seluruh daerah tingkat dua, (6) Terdapatnya sumber daya manusia seperti: pelatih yang handal dalam membuat dan menjalankan program latihan berdasarkan IPTEK olahraga, perekrutan atlet potensial tepat, peran dan dukungan serta partisipasi masyarakat, (7) lingkungan yang kondusif berupa dukungan geografis daerah dan industri terhadap olahraga unggulan daerah.

Komitmen dan kebijakan pimpinan daerah Provinsi Papua dalam pembinaan olahraga khususnya cabang olahraga unggulan Provinsi Papua tersebut, sangat dibutuhkan karena akan memberikan pengaruh positif pada pencapaian prestasi olahragawan di Papua yang selanjutnya akan memberikan kontribusi pada prestasi olahraga Nasional. Prestasi olahraga Nasional tidak akan berarti kalau tidak didukung oleh prestasi olahraga didaerah yang baik. Keberadaan organisasi keolahragaan sangat mempengaruhi keberhasilan prestasi olahraga itu sendiri. Salah satu indikator keberhasilan prestasi olahraga juga dilihat dari berfungsinya organisasi secara maksimal. Selain itu kinerja organisasi keolahragaan harus memperhatikan sasaran yang akan dicapai, yaitu pencapaian prestasi puncak pada olahragawan atau atlet, cara mengatasi kritis, konsisten dengan nilai dan keyakinan, bertindak mandiri, berkomunikasi dengan baik, memperhatikan masukan, taat pada peraturan, dan ketepatan dalam penggunaan waktu, sehingga pencapaian harapan masyarakat dapat terwujud.

\section{b. Sumber Daya Manusia}

Aspek sumber daya manusia dapat dilihat dari beberapa indikator seperti; 1) Jumlah Pelatih, 2) Kualifikasi Pelatih, 3) Jumlah Atlet Senior, 4) Jumlah Atlet Yunior dan, 5) Animo Masyarakat.

Sebagai mana yang telah dipaparkan pada hasil penelitian tentang indikator tersebut diatas, memang masih sangat memprihatinkan. Mulai dari SDM pelatihnya baik dari segi kuantitas lebih-lebih dari segi kualitas sangat jauh dari apa yang seharusnya dimiliki daerah seperti Papua yang mempunyai potensi besar dalam hal sumber bibit atlet potensial jika dibandingkan dengan daerah lain yang jumlah SDM pelatihnya sangat memadai baik kuantitas maupun kulaitasnya. Dari tiga cabang olahraga yang sudah merupakan olahraga unggulan Papua ditambah beberapa cabor lagi yang diharapkan dapat menyumbangkan medali emas pada PON XX di Papua pada tahun 2020 dengan harapan bisa mengangkat rangking Provinsi Papua menjadi yang terbaik diluar pulau jawa, ternyata hanya mempunyai SDM pelatih keseluruhan sebanyak 143 orang dengan tiga kategori atau level yaitu; pelatih yang mempunyai sertifikat Internasional 3 orang, sertifikat Nasional 23 orang dan sertifikat daerah hanya 117 orang dengan jumlah wasit pada cabang olahraga dengan 3 kategori sebanyak 18 orang.

Begitu juga dengan SDM dibidang olahragwan atau Atlet baik atlet senior maupun atlet yunior masih sangat terbatas. Jumlah atlet senior hanya 180 orang sedangkan yunior 695 orang. Suatu jumlah yang sangat kecil dibandingkan dengan daerah lain dijawa yang jumlah atlet yuniornya mencapai angka ribuan yang dua bahkan tiga kali lebih besar dari yang dimiliki Papau baik yunior maupun atlet seniornya.

Demikian juga mengenai animo masyarakat terhadap cabang-cabang olahraga unggulan belum begitu populer dan masih jarang peminatnya. Animo masyarakat yang kelihatan banyak untuk setiap kali ada kejuaraan barulah pada cabang olahraga sepak bola sebagai olahraga rakyat yang sudah memasuki dunia industri. Cabang olahraga lainnya yang termasuk animo masyarakatnya tinggi saat digelar pertandingan dengan ukuran banyaknya penonton adalah; tinju, kemudian bola Voli, sedangkan cabang lain masih sangat minim dari segi animo masyarakat berdasarkan penonton yang datang menyaksikan jika ada pertandingan.

\section{c. Pembinaan Secara Bertahap.}

Indikator tentang pembinaan olahraga unggulan di Provinsi papua dapat dilihat dari dua indikator yaitu; 1) Sistim Pembibitan dan, 2) Program Pembinaan. Sistim pembibitan sudah dilakukan dengan bekerja sama dengan instansi terkait seperti Diknas melalui pembinaan olahraga usia dini melalui klub-klub olagraga sekolah. Pembinaan olahraga usia dini di provinsi Papua setiap tahun selalu mengikuti POR usia dini yang diselenggarakan setiap bulan Agustus oleh Depdiknas pusat dan sampai tahun 2016 ini telah melombakan 13 cabang olahraga dan Provinsi Papua tidak pernah absen. Hal serupa juga dilakukan oleh Disorda Provinsi Papua dengan membina PPLP (Pusat Pendidikan dan Latihan Pelajar) 
dengan 14 cabor. Ini membuktikan bahwa pembibitan atlet potensial di provinsi Papua melalui pembinaan olahraga usia dini selalu mendapat respon dari pemerintah daerah termasuk cabor unggulan yang ada sekarang ini.

Program pembinaan secara berjenjang selanjutnya dilakukan oleh pemerintah daerah Provinsi Papua melalui usia dini. Dengan adanya PPLP dan PPLM berarti bahwa kelanjutan dari pembibitan melalui pembinaan olahraga usia dini di sekolah dasar dapat dilanjutkan dengan memasukkan anak yang potensial kedalam pembinaan selanjutnya melalui PPLP dan PPLM. Hanya saja belum semua anak yang berpotensi dapat masuk ke PPLP diakibatkan tempat yang ada di PPLP sangat terbatas. Begitu pula pada jenjang Perguruan Tinggi baru sebatas pada cabang atletik saja, sehingga cabang olahraga unggulan lainnya harus memaksimalkan pembinaan lewat club-club dibawah pembinaan induk organisasi cabang olahraga masing-masing. Hanya saja ketersediaan fasilitas yang ada sekarang di PPLP belum sebanding dengan jumlah cabor yang seharusnya masuk PPLP. Begitu juga dengan jumlah cabor yang ada di PPLP belum sinergi dengan cabor yang di bina oleh Koni Papua. Keberadaan 3 wadah pembinaan yang ada sekarang ini untuk mendukung program Koni yaitu Usia Dini, PPLP dan PPLM. PPLP baru membina 14 cabor sedangkan jumlah cabor yang di bina Koni Provinsi Papua sudah 42 cabor, sehingga banyak cabor yang harus jatuh bangun membina cabornya karena jalur dibawahnya seperti usia dini dan PPLP jumlah cabor binaannya masih sangat terbatas.

\section{d. Sarana Prasarana Olahraga Unggulan.}

Ketersediaan sarana prasarana bagi olahraga unggulan Provinsi Papua memang masih menjadi kendala utama dalam pembinaan cabang olahraga prestasi di Provinsi Papua lebih khusus bagi olahraga unnggulan. Pada umumnya atlet dengan bakat alamnya hanya bisa berlatih dengan sarana seadanya dan masih jauh dari standar yang disyaratkan induk organisasinya masing-masing.

Bagi Cabang olahraga unggulan seperti atletik dengan berbagai nomor yang dilombakan belum semua Kabupaten di Provinsi Papua yang dapat menyediakan sarana berlatih seperti lintasan lari yang standard. Baru ada 3 daerah yang mampu membuat lintasan, sehingga penyebaran dari sarana dan prasarana berlatih untuk olahraga unggulan khususnya atletik masih belum merata. Begitu juga dengan Dayung yang hanya dapat berlatih secara intensif di danau sentani sedangkan daerah lain belum ada pembinaan yang serius. Cabang Pabsi yang secara konsisten memberikan kontribusi medali emas dalam 5 PON berturut-turut juga mengalami kendala yang sama dengan atletik dan dayung masalah sarana prasarana latihan. Khusus untuk Pabsi yang mengandalkan bina raga dan angkat besi yang selalu meraih medali emas dalam 5 PON terahir juga masih sangat prihatin dalam hal sarana latihan. Kalau mengharapkan sarana yang disediakan oleh induk organisasi cabor maupun KONI tidak akan tercukupi karena alat jumlah alat dengan atlet yang berlatih tidak seimbang. Pabsi hanya bisa terbantu dari adanya tempat fitnes dibeberapa tempat yang bisa digunakan oleh beberapa atlet seperti binaraga dimana atletnya bisa merangkap sebagai trainer.

\section{e. Lingkungan}

Akar olahraga selalu berasal dari ekspresi sifat alami manusia berupa budaya, maka sejarah olahraga adalah juga sejarah rakyat sebagaimana asal usul dari sepakbola dan rugby yang adalah awal kisah dari kelompokkelompok masyarakat di Ingris (Suratman, 2015:257).

Dengan melihat kondisi daerah Papua yang bergunung-gunung ditambah karasteristik orang Papua yang tercipta dan lahir dari pola hidup mereka yang serba keras dan menantang tersebut, maka olahraga yang cocok bagi mereka adalah olahraga perorangan yang keras dan menantang seperti ; Tinju, Gulat, Karate, Pencak Silat, Yudo serta atletik dan angkat berat serta cabor beladiri lainnya seperti Muaythai, tarung derajat, kempo dan taekwondo. Cabang olahraga beregu seperti sepak bola dan hockey. Hal ini dapat dikatakan demikian karena cabang olahraga terbut semuanya bersifat menantang khususnya pada cabang olahraga bela diri yang dapat melambangkan suatu lambang keperkasaan jika dapat memenangkan pertandingan. Jika dilihat dari cara mereka bercocok tanam dengan cara yang berpindah-pindah, maka hal ini juga dapat menggambarkan kalau mereka tidak dapat menggunakan waktu yang begitu lama pada suatu tempat dan ini berindikasi pada ciri khas dan karakter dalam menekuni cabang olahraga masing-masing. Dengan demikian maka orang Papua boleh dikatakan cocok terhadap cabang olahraga keras dan tidak memakan waktu yang begitu lama. Dayung kenapa menjadi cabor unggulan, karena masyarakat di sekitar danau sentani sebagian besar mata pencahariannya adalah menangkap ikan atau nelayan sehingga tidak terlalu sulit bagi mereka dalam memacu perahu karena sudah menjadi kebiasaan dalam hidupnya sehari-hari untuk mendayung perahu menangkap ikan. Sebenarnya panahan juga seharusnya menjadi cabor unggulan karena panah merupakan bagian dari budaya orang papua untuk berperang, namun sampai sekarang cabor ini kurang berkembang di Papua sendiri diabanding cabor lainnya.

\section{f. Olahraga yang diunggulkan}

Dalam aspek olahraga yang diunggulkan tersebut dapat dilihat dari 3 indikator yaitu; 1) Jenis Olahraga, 2) Perolehan medali emas dan, 3) Potensi perolehan medali pada PON XX tahun 2020 di Papua. Seperti yang telah diuraikan diatas bahwa jenis cabang olahraga unggulan untuk Provinsi Papua adalah dominan olahraga perorangan seperti; Atletik, dayung, angkat berat, angkat besi dan bina raga. Cabang olahraga inilah yang selama 5 PON terakhir masih menyumbangkan medali emas secara konsisten. Kemudian cabang olahraga lainnya seperti Tinju, karate, Pencak Silat dan Yudo dan gulat serta cabang olahraga rakyat yang beregu yaitu sepakbola, voli, basket dan hockey. Juga merupakan Cabang olahraga yang selama 5 PON terakhir masih menyumbangkan medali pada kontingen Papua namun tidak konsisten. Dengan terverifikasinya beberapa cabang beberapa cabang olahraga unggulan papua tersebut di atas maka potensi penambahan perolehan medali bagi Provinsi Papua pada PON XX tahun 2020 di Papua sangat terbuka dan mentargetkan berada pada rangking $\mathrm{V}$ dengan perkiraan perolehan medali emas antara 25-35 buah. Mencermati hasil PON XIX/2016 jawa barat terlihat bahwa perolehan medali Jawa barat selaku tuan rumah sangat pantastik dengan merebut lebih dari 200 medali emas. Keadaan ini selama pelaksanaan PON yang sudah ke 19 kalinya belum pernah dicapai oleh daerah yang pernah menjadi juara umum sebelumnya seperti DKI dan Jawa timur.

\section{Simpulan dan Saran}

Berdasarkan uraian hasil penelitian di atas, maka dapat diambil kesimpulan yaitu :

1. Peran Pemerintah Daerah dalam bentuk Komitmen dan Kebijakan dalam membina cabang olahraga Unggulan di Provinsi Papua sudah berjalan dengan baik.

2. Ketersediaan SDM Olahraga di Papua untuk membecup tuntutan Iptek yang semakin hari semakin berkembang masih sangat kurang.

3. Pembinaan olahraga secara bertahap melalui Usia dini, PPLP dan PPLM sudah dilakukan namun belum optimal.

4. Ketersediaan dan penyebaran sarana dan prasarana olahraga unggulan di daerah belum merata dan masih terbatas pada ibukota Kabupaten/Kota dan Provinsi.

5. Faktor Lingkungan berupa letak geografis dan kartakteristik serta budaya, orang Papua cocok untuk olahraga perorangan yang menantang.

6. Profil Olahraga unggulan Provinsi Papua berdasarkan perolehan medali 5 PON terakhir adalah; Atletik, Dayung dan Pabsi.

7. Potensi provinsi Papua dalam perolehan Medali emas pada PON XX tahun 2020 di Papua ditargetkan 25-35 medali Emas dan menduduki rangking 5 besar. 
Sedangkan berdasar hasil simpulan di atas maka diberikan rekomendasi sebagai berikut:

1. Cabang Olahraga yang menjadi unggulan bagi provinsi papua sebaiknya cabang olahraga yang sifatnya menantang dan tidak memerlukan waktu tanding yang lama seperti : Atletik nomor sprint, nomor lempar dan lompat, angkat besi, angkat Berat dan binaraga serta bela diri.

2. KONI Papua hendaknya membina cabang olahraga perorangan yang mempunyai potensi meraih medali emas pada PON, SEA Games, Asian Games maupun Olympiade.

3. Profil cabang olahraga unggulan Papua hendaknya tidak hanya dilihat dari segi perolehan medali emas, tetapi juga dilihat dari segi yang mendukung pembinaan cabang olahraga tersebut seperti; Komitmen Pemerintah, Organisasi, Sarana Prasarana, SDM dan Kompetisi

\section{Daftar Pustaka}

Depdiknas, 2004. Indikator Olahraga Indonesia (Kerjasama Badan Pusat Statistik dan Direktorat Jenderal Olahraga, Jakarta,

Hadi, Sutrisno. 1993. Metodologi Research. Jakarta: Andi Offset.

Harsuki. 2003. Perkembangan Olahraga Terkini Kajian Para Pakar. Jakarta: PT. Raja Grafindo Persada.

Lutan Rusli, MF. Siregar, dan Tahir Jide, , 2004. Akar Sejarah dan Dimensi Keolahragaan Nasional, Jakarta: Direktorat Jenderal Olahraga, Depdiknas.

Muller, Kal, 2011. Pesisir Selatan Papua, First Edition, Indonesia: DW Books.

Mutohir ,T. Cholik, 2004. Olahraga dan Pembangunan, Jakarta: Proyek Pengembangan dan Keserasian Kebijakan Olahraga, Dirjen Olahraga, Depdiknas.

Pattipi, Jakob, 1993. Etnografi Irian Jaya, Panduan Sosial Budaya, Uncen Pers,

Puslit Uncen, 1997. Pemetaan social budaya di Kabupaten Merauke, FakFak dan Jaya wijaya. Jayapura: Uncen Press.

Suratman, Tono, 2015. Strategi Olahraga Nasional Abad 21, Jakarta: Verbun Publising.

Undang-Undang Republik Indonesia Nomor 3 tahun 2005, Sistim Keolahragaan Nasional, Jakarta: Kementerian Negara Pemuda dan Olahraga. 